\section{Crack width variation within the concrete cover of reinforced concrete members}

\author{
AdoRJÁN BOROSNYÓI - BME Dept. of Construction Materials and Engineering Geology \\ - adorjan.borosnyoi@gmail.com \\ IvÁN SNÓBLI - BME Dept. of Construction Materials and Engineering Geology \\ Received: 31.07.2010. - Érkezett: 2010.07.31. http://dx.doi.org/10.14382/epitoanyag-jsbcm.2010.14
}

\begin{abstract}
Crack width in reinforced concrete structures is usually considered to be constant within the concrete cover by design codes. This simplification can lead to inaccurate or uneconomical design and it is completely misleading for a possible crack repair design. Aim of present experimental studies is to investigate the application possibilities of PU injection resins for active cracks in dynamically loaded structural concrete members. Present paper summarizes the results of the preliminary studies carried out with epoxy injection resin for a detailed survey of the variation of crack widths within the concrete cover of reinforced concrete tensile members. The paper highlights the significance of different concrete covers on the variation both of internal and surface crack widths, confirms several findings of previous studies including the influence of the so-called Goto cracks, and appreciates the recently developed proposal of the fib Model Code 2010 concerning the variation of the crack width along the concrete cover in the form of a power function.

Keywords: crack width, crack pattern, concrete cover, resin injection
\end{abstract}

Dr. Adorján BOROSNYó

Civil engineer (MSc), PhD, Associate Professo at BME Dept. of Construction Materials and Engineering Geology. Main fields of interest: cracking and deflection of reinforced concrete, application of non-metallic (FRP) reinforcements for concrete structures, bond in concrete, nondestructive testing of concrete. Member of the fib Task Group 4.1 "Serviceability Models" and Chairman of the SZTE Concrete Division.

Iván SNÓBLI Civil engineer (BSC) student at BME Dept. of Construction Materials and Engineering Geology. Main fields of interest: cracking of reinforced concrete, injection of cracks in concrete, use of polymer resins in concrete construction.

\section{Introduction}

Cracking of concrete structures due to bending or tension has usually great significance on structural behaviour. Structural cracks can influence both serviceability and durability of structural members. From the serviceability point of view, the reduction of stiffness and increase of deformations, the possible water leakage through the cracks and the aesthetical concerns can be mentioned. From the durability point of view, the possible attack of steel corrosion and the reduced service life of structures can be in focus. Several papers discussed the impact of crack width on the corrosion of steel embedded in concrete $[1,2,3,4,5,6]$. Results are controversial, however, it was clearly demonstrated that the corrosion tendency and rate of corrosion of steel embedded in concrete are independent from the surface crack widths and can be considerably accelerated in the presence of chloride ions. The pattern and width of the cracks inside the concrete cover is frequently different from that observed on the surface of the member, nevertheless, structural cracks usually follow the stress trajectories developed by loading $[7,8,9,10,11]$. Structural cracking of reinforced concrete can be avoided only with full prestressing.

The repair methods are different during the repair of unexpected or excessive cracking of concrete according to the targeted objective of the repair that can be the restoration of strength or stiffness, the improvement of the functional performance (e.g. watertightness), the improvement of appearance or the improvement of durability. Methods cover resin injection, routing and sealing technique, grouting, drypacking, gravity filling, impregnation and overlays or surface coatings. Repair methods also depend on the expected behaviour of the cracks (i.e. stabilized or active cracks).

\section{Significance and objectives of present studies}

Technical literature and practical repair experiences demonstrated that force transmitting injection of concrete by epoxy resins is possible through cracks having widths higher than $0.05 \mathrm{~mm}$ [12]. On the other hand, dynamically loaded structural members could not be sealed with epoxy resins as they are rather brittle polymers. Elastomeric or PU resins are available for the permanent sealing of active cracks. The dynamic crack movements can be absorbed by the flexibility of these resins. Secure sealing needs the resin to be available in adequate thickness, therefore, the dynamic crack bridging action of the resins is supposed to be violated for small crack widths like that of $0.05 \mathrm{~mm}$.

Present experimental studies targeted the laboratory testing of low viscosity PU injection resins within cracks of the widths of 0.05 to $0.50 \mathrm{~mm}$. Main focus of the studies is the dynamic crack bridging action and sealing capacity of resins within cracks of small crack widths. Present paper summarizes the results of the preliminary studies on mapping of internal crack widths within the concrete cover of reinforced concrete tensile elements.

\section{Previous studies}

It is indicated in the technical literature that the surface crack width of structural elements can be considerably higher than the crack width available at the level of the steel reinforcement. Results demonstrated that surface crack widths may be two to ten times the crack width close to the steel reinforcement $[2,7,8,10,11]$. It was also found that despite cracks are originated at the surface of the steel reinforcement they are often confined to almost zero width at the very vicinity of the steel reinforcement. Fig. 1. gives experimental result of Beeby (1978) indicating considerable differences between surface 
crack width and crack width close to the steel reinforcement [2]. Husain and Ferguson (1968) found that the crack width at the level of the steel reinforcement is independent from the thickness of the concrete cover but the surface crack widths were found to be proportional with the thickness of the concrete cover [8]. Results of Broms (1965) confirmed these findings and it was also demonstrated that the surface crack width is almost linearly proportional with the tensile stress in the steel reinforcement but the influence eliminates near to the reinforcement [7]. Similar conclusions were found by Tammo and Thelandersson (2006) [11].

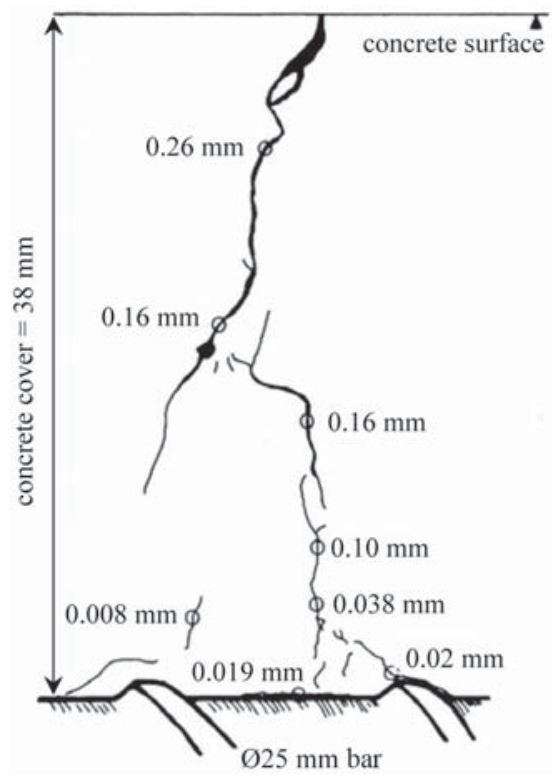

Fig. 1. Variation of crack width within a concrete cover of $38 \mathrm{~mm}$ [2]

1. ábra Repedéstágasság változása $38 \mathrm{~mm}$-es betonfedésen belül [2]

\section{Testing method}

Reinforced concrete tie elements of $120 \times 120$ mm cross section and $900 \mathrm{~mm}$ length were prepared for present experimental studies with one single $\varnothing 20 \mathrm{~mm}$ deformed steel reinforcing bar placed either concentrically or eccentrically. Concrete covers were 20,40,60, $80 \mathrm{~mm}$ for the eccentric specimens and $50 \mathrm{~mm}$ for the concentric specimens. Self compacting concrete of $f_{\mathrm{cm}}$ $=82.6 \mathrm{~N} / \mathrm{mm}^{2}$ average standard cube compressive strength was used. Specimens were loaded monotonically, deformation controlled (at a loading rate of $0.5 \mathrm{~mm} / \mathrm{min}$ ) with a $600 \mathrm{kN}$ capacity universal testing machine (Instron 1197) up to a stabilized cracking condition with maximum surface crack width of at least $0.30 \mathrm{~mm}$. Typical test arrangement is given in Fig. 2. Load-deformation responses were recorded digitally with a HBM Spider8 multi-channel electronic PC measurement unit and a portable computer with HBM Catman professional measurement software. Loading never exceeded the maximum load of $150 \mathrm{kN}$ to avoid yielding of the steel reinforcement. The applied actual maximum load was maintained for 12 to 18 hours during which the structural cracks were injected and the resin was allowed to set. Main focus of present studies was on the structural cracks that reach the concrete surface to be injected, therefore, the injection was carried out from the surface of the members through plastic injecting packers. As being a preliminary study for the upcoming PU injection tests, the detailed mapping of the internal crack width variation within the concrete cover was targeted during the tests. Therefore, high strength, brittle epoxy resin was selected for the injection. Cracks were sealed at the concrete surface before injection by a rapid set epoxy resin (MC-Quicksolid ${ }^{\circ}$ ) and the injection was carried out by a very low viscosity ( $95 \mathrm{mPa} \cdot \mathrm{s}$ ), high strength $\left(85 \mathrm{~N} / \mathrm{mm}^{2}\right)$ injection epoxy resin (MC-DUR $1264 \mathrm{KF}^{\circ}$ ). The cracks were maintained in their original, loaded position and the axial load was released only after the resin was allowed to set. Surface crack pattern and surface crack widths were recorded and then the specimens were cut open by a high speed diamond saw to make the crack widths visible throughout the concrete cover. Crack widths were recorded by a hand microscope (magnification of $0.01 \mathrm{~mm}$ ) at every 2 $\mathrm{mm}$ along each crack. Typical detail is shown in Fig. 3. In this way, eight cut surfaces were available for each crack. Concrete compressive strength and Young's modulus tests were also carried out on the same day of the injection to complete the tests.

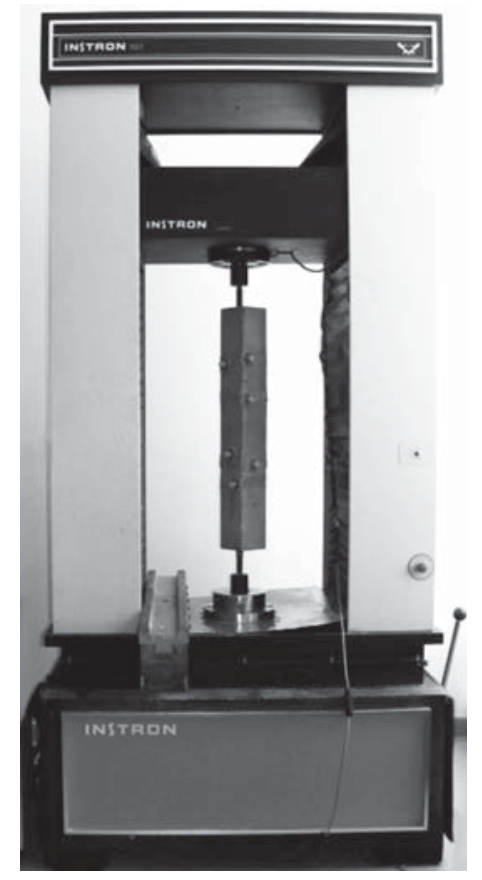

Fig. 2. Typical test arrangement

2. ábra Jellegzetes vizsgálati elrendezés

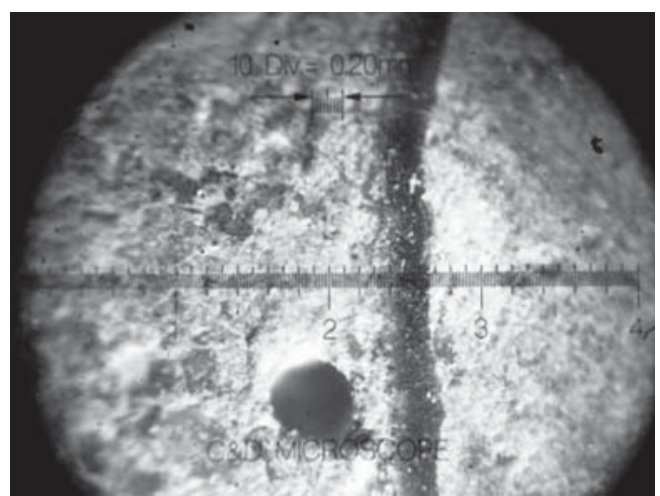

Fig. 3. Typical detail of crack width reading

3. ábra Repedástágasság leolvasás jellegzetes részlete 

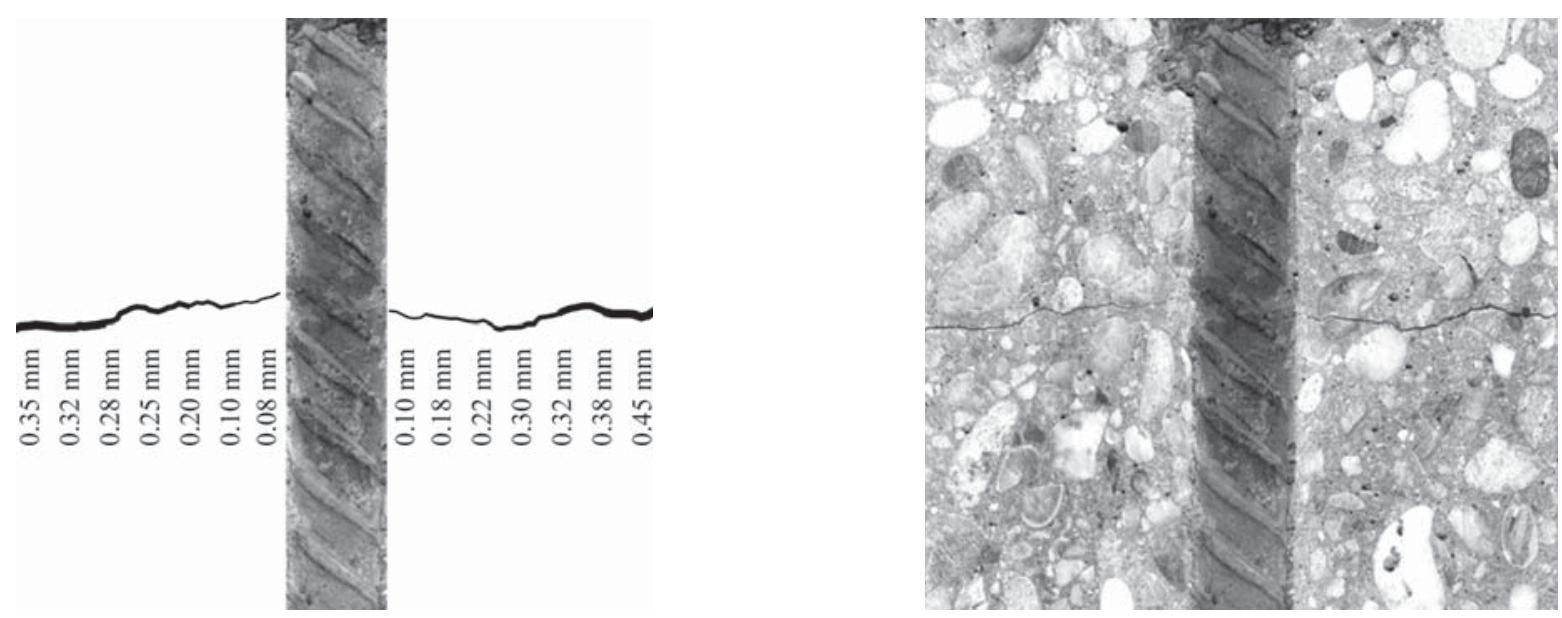

Fig. 4. Variation of crack width for specimen with concentric steel reinforcement (concrete cover of $50 \mathrm{~mm}$ )

4. ábra. Repedéstágasság változása központosan elhelyezett acélbetét mellett (50 mm betonfedés)

\section{Results and discussion}

Surface crack widths were recorded both under loading and following the release of the axial load - after the injection resin was allowed to set. It was realized that the surface crack widths did not change by the unloading procedure, therefore, the injection was found to be effective and the cracks can be supposed to be maintained in their original, as loaded position. The cut open specimens demonstrated that the injection material was able to penetrate as deep as the level of the steel reinforcement, filling all the cracks even with the smallest crack widths of 0.01 to $0.02 \mathrm{~mm}$. The resin filled cracks were visible and all the crack widths could be read accurately. One representative result for a specimen with concentric position of the steel reinforcement (concrete cover of $50 \mathrm{~mm}$ ) is indicated in Fig. 4.

Readings of crack widths along the concrete cover corresponding to a specimen with eccentric position of the steel reinforcement (concrete covers of 20,40,60,80 mm) are indicated in Fig. 5. It can be realized that the variation of the crack width is non-uniform and nonlinear along the concrete cover. Results also indicate that the different concrete covers result in different local stiffnesses of the tensile member. Higher stiffness parts apparently collect the deformations and higher crack widths are resulted. If one compares the observed crack widths at a distance of e.g. $20 \mathrm{~mm}$ from the steel reinforcement $0.11 \mathrm{~mm}, 0.15 \mathrm{~mm}, 0.20 \mathrm{~mm}$ and $0.32 \mathrm{~mm}$ could be found corresponding to the concrete covers of $20 \mathrm{~mm}, 40 \mathrm{~mm}, 60 \mathrm{~mm}$ and $80 \mathrm{~mm}$, respectively. On the other hand, the crack width at the level of the steel reinforcement is found to be independent from the actual concrete cover that is in accordance with the results introduced in the technical literature.

A further remarkable phenomenon can be also seen in Fig. 5: the tendency of the change of the crack width is considerably different in the close vicinity of the steel reinforcement (i.e. within a distance of 10 to $15 \mathrm{~mm}$ ) than in the outer parts of the concrete cover. The apparent limits of these areas are indicated with arrows in the diagrams and seem not to be depending on the actual concrete cover. These observations confirm the presence of secondary micro-cracks (i.e. Goto cracks) at the surface of the steel reinforcement (schematically shown in Fig. 6. after Goto, 1971 [9]). The secondary micro-cracks represent a smeared deformation field in the close vicinity of the steel reinforcement and influence the crack width of the macroscopic
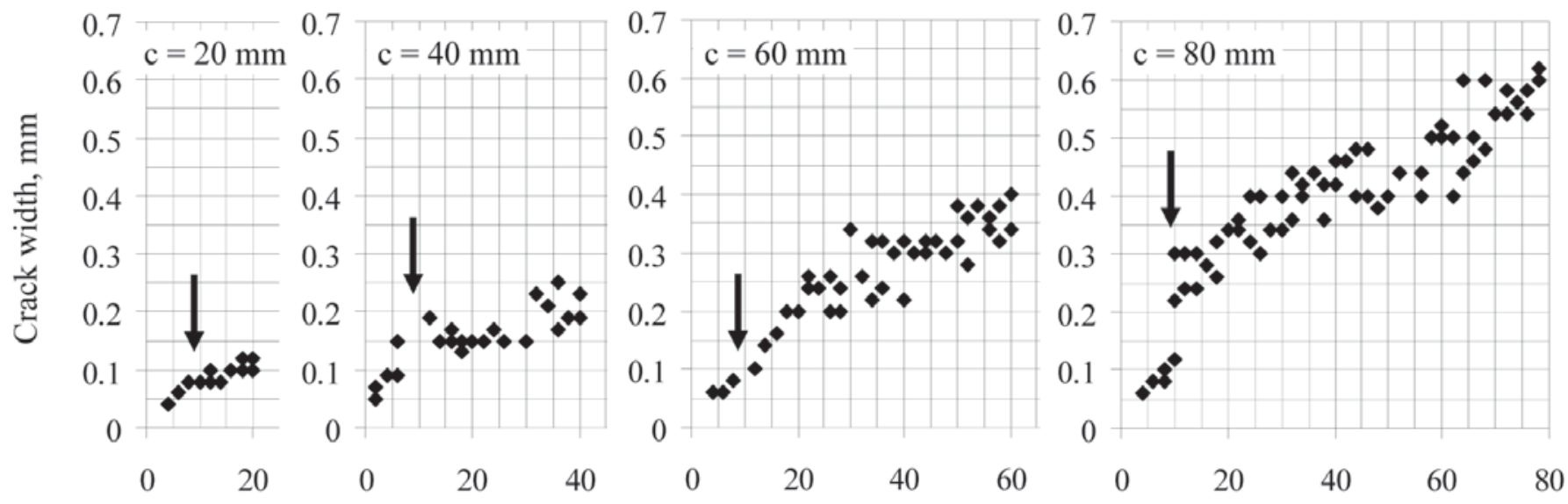

Distance from the steel reinforcement, $\mathrm{mm}$

Fig. 5. Variation of crack width for specimens with eccentric steel reinforcement (concrete covers of 20, 40, 60, $80 \mathrm{~mm}$ )

5. ábra Repedéstágasság változása külpontosan elhelyezett acélbetét mellett (20, 40,60, $80 \mathrm{~mm}$ betonfedés) 
structural cracks. Outside this region the deformation of the concrete cover governs the variations of the crack widths.

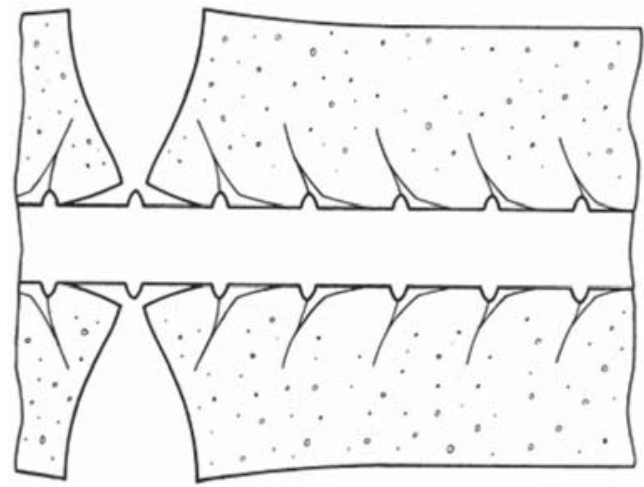

Fig. 6. Schematic representation of secondary micro-cracks (Goto cracks) at the surface of the steel reinforcement [9]

6. ábra Acélbetét felületén kialakuló másodlagos mikro-repedések (ún. Gotorepedések) sematikus ábrázolása [9]

\section{The role of the concrete cover}

Neither design codes nor technical papers or reports give indication about the variation of crack width within the concrete cover or the increase of surface crack width due to increasing concrete cover, however, it could be an important part of serviceability limit state (SLS) design. Calculated (design) crack widths are usually determined at the level of the steel reinforcement and the crack width is assumed to be constant over the concrete cover. The Chapter 7.6 of the fib Model Code 2010 first complete draft document is the only design code available in which one can find a reference to the influence of concrete cover on crack width [13]. The Model Code 2010 proposes a generalized formula to find the crack width $\left(w_{d}{ }^{*}\right)$ at any distance from the steel reinforcement as follows:

$$
w_{d}^{*}=w_{d}+\Delta w_{d}
$$

where: $w_{d} \quad$ denotes the design crack width calculated at the level of the steel reinforcement

$\Delta w_{d} \quad$ denotes the crack width increase within the concrete cover due to shear lag that has to be calculated as a function of the concrete cover $(c)$. The general form of the function is $\Delta w_{d}=A \times c^{\beta}$, where $A$ is a function of concrete compressive strength $\left(f_{c m}\right)$ and the effective reinforcement ratio $\left(\rho_{s, e f}\right)$ and $\beta$ is an empirical constant $0<\beta<1$

It can be seen that the Model Code 2010 does not provide a proposal that can be used directly, only the supposed relationship is given between the concrete cover and the crack width [13].

Present experimental results, however, confirm the supposed existence of a power function that could be found between the concrete cover and the variation of the crack width. Fig. 7 . represents the measured data given earlier in Fig. 5 together with power function trend curves determined with regression analysis. It can be realized that the variation of the crack width along the concrete cover can be described reasonably well with power functions. Parameter analysis is not possible to be carried out for present experimental results as only one type and strength of concrete as well as one reinforcement ratio was applied. The empirical constant $\beta$ was found to be in the range of $\beta=0.4$ to 0.7 that further ratifies the supposed relationship given in the Model Code 2010. Present experimental results indicate the need of further laboratory studies in the field.

\section{Conclusions}

Present paper summarized the results of preliminary studies on the variation of crack widths within the concrete cover of reinforced concrete tensile members. During present tests the specimens (both with concentrically and eccentrically placed steel reinforcements) were precracked and injected with low viscosity, high strength epoxy resin. Results demonstrated that the selected injection material is suitable to maintain the structural cracks in their original, loaded position after
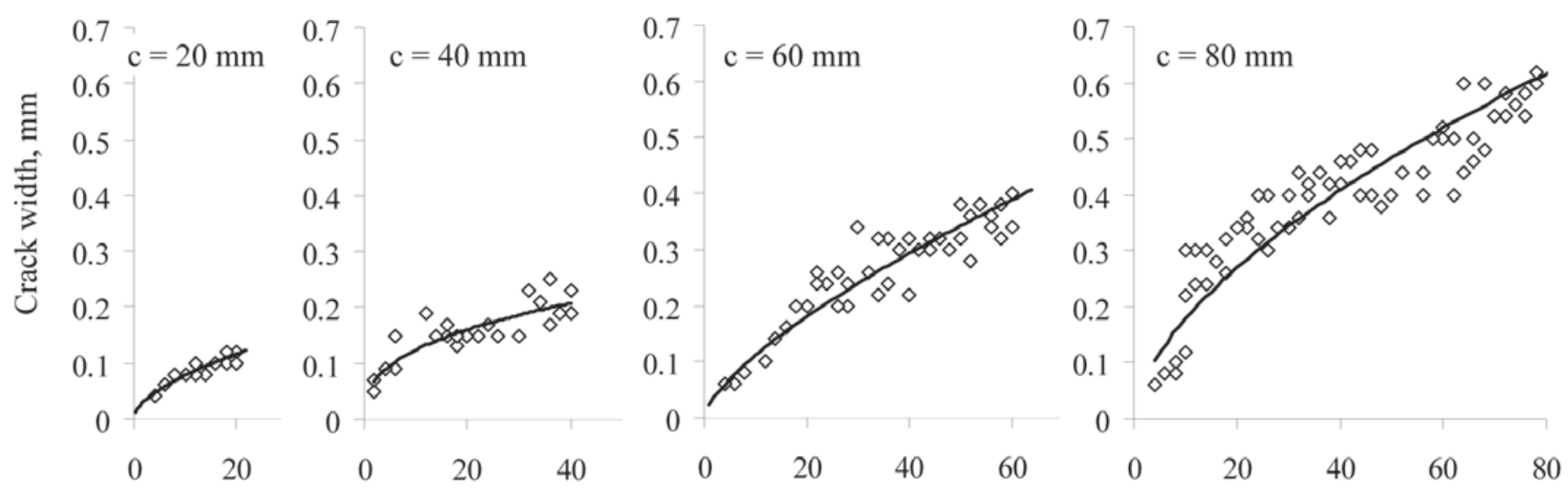

Distance from the steel reinforcement, $\mathrm{mm}$

Fig. 7. Regression power function curves for the variation of crack width for specimens with eccentric steel reinforcement (concrete covers of 20, 40, 60, 80 mm)

7. ábra Repedéstágasság betonfedésen belüli változásának ábrázolása hatványfüggvény alakjában; külpontosan elhelyezett acélbetét (20, 40, 60, 80 mm betonfedés) 
releasing the axial load. The observed variation of crack widths confirmed the results of previous studies by several authors. It was demonstrated that the surface crack width is strongly dependent on the actual concrete cover, however, the crack width at the level of the steel reinforcement was found to be independent from the concrete cover. Test results clearly indicate the influence of secondary micro-cracks (Goto cracks) on the crack width of the macroscopic structural cracks and the possible extent of the micro-cracked zone around the steel reinforcement was also localized. Test results confirm the potential of the proposal of the $\boldsymbol{f i b}$ Model Code 2010 for the relationship between the concrete cover and the crack width in the form of a power function. The preliminary studies resulted detailed general information about the internal crack pattern and crack width variation within the concrete cover providing an appropriate preparation for the PU injection resin studies.

\section{Acknowledgements}

The authors gratefully acknowledge the technical assistance of Mr. Csaba Pethö, Mr. Péter Kirinovics, Mr. Péter Kávai, Mr. József Minkovits and Mr. Márk Hatala during the specimen preparation and injection tasks. The authors express their gratitude to Mr. László Hégely (MC Bauchemie Ltd.) for providing test materials. The authors appreciate the help of Mr. Péter Tisza, Ms. Enikő Kácsor, Mr. Daniel Aldous and Ms. Katalin Szilágyi during laboratory measurements and evaluations. The authors are obliged to Dr. Andor Windisch for the thorough proofread of the manuscript.

\section{References}

[1] Schiessl, P.: Zur Frage der zulässigen Rissbreite und der erforderlichen Betondeckung im Stahlbetonbau unter besonderer Berücksichtigung der Karbonatisierung des Betons, Deutscher Ausschuss für Stahlbeton, Heft 255, Berlin, 1976

[2] Beeby, A. W.: Corrosion of reinforcing steel in concrete and its relation to cracking, The Structural Engineer, March 1978, pp. 77-81.

[3] Rehm, G., Frey, R., Nürnberger, U.: Versuche zur Ermittlung der Korrosionsempfindlichkeit von Bewehrungsstählen, insbesondere aber von Spannstählen bei teilweise vorgespannten Bauwerken, Forschung Strassenbau und Strassenverkehrstechnik, Heft 309, 1989

[4] Kellner, T., Menn, C.: Der Einfluss von Rissen auf die Bewehrungskorrosion, Beton- und Stahlbetonbau, Heft 2, 1993, pp. 47-51.

[5] Otsuki, N., Miyazato, S., Diola, N. B., Suzuki, H.: Influences of Bending Crack and Water-Cement Ratio on Chloride-Induced Corrosion of Main Reinforcing Bars and Stirrups, ACI Materials Journal, Vol. 97, Issue 4, July 2000, pp. 454-464.
[6] Darwin, D., Lindquist, W., Browning, J., Miller, G.: Effect of Cracking on Chloride Content in Concrete Bridge Decks, ACI Materials Journal, Vol. 103, Issue 6, July 2006, pp. 467-473.

[7] Broms, B.: Crack width and crack spacing in reinforced concrete members, ACI Journal October 1965, pp. 1237-1256.

[8] Husain, S. I., Ferguson, P. M.: Flexural Crack Widths at the Bars in Reinforced Concrete Beams. Center for Highway Research, The University of Texas at Austin, Research Report No. 102,1F, 1968.

[9] Goto, Y.: Cracks formed in concrete around deformed tension bars, ACI Journal, April 1971, pp. 244-251.

[10] Yannopoulos, P. J.: Variation of concrete crack widths through the concrete cover to reinforcement. Magazine of Concrete Research, 1989, 41, No. 147, pp. 63-68.

[11] Tammo, K., Thelandersson, S.: Crack opening near reinforcement bars in concrete structures. Structural Concrete, 2006, 7, No. 4, pp. 137-143.

[12] ACI (American Concrete Institute): Causes, Evaluation, and Repair of Cracks in Concrete Structures, ACI 224.1R-07, 2007, 22 p.

[13] fib (fédération internationale du béton): Model Code 2010 First complete draft, Vol. 2., fib Bulletin No. 56, 2010, 288. p.

\section{A repedéstágasság változása vasbeton elemek betonfedésén belül}

Jelen cikk összefoglalta húzott vasbeton elemek terhelés alatt kiinjektált repedései repedéstágasságának vizsgálatát. Az eredmények igazolták, hogy a kiválasztott injektáló anyaggal a legkisebb repedéstágasságú repedések is kitölthetốek injektáló anyaggal, és a repedések a megterhelés során kialakult állapotukban tarthatók tehermentesítést követôen is. Az injektáló anyaggal telített próbatesteket kôvágó géppel felvágtuk, és a repedéstágasságok változását a betonfedésben fölmértük. Az eredmények rámutattak, hogy a betonelem felszínén mérhetố repedéstágasság nemlineárisan függ az aktuális betonfedéstốl, ugyanakkor a betonacél felületén kialakuló repedéstágasság mértéke nem függ a betonfedés mértékétôl. A vizsgálatok igazolták a betonacélok körül kialakuló másodlagos mikro-repedések (ún. Goto-repedések) jelenlétét és rámutattak e zóna kiterjedésének mértékére. Az eredmények alátámasztják a fib Model Code 2010 nemzetközi mintaszabvány javaslatát, amely a repedéstágasság betonfedésen belüli változását hatványfüggvény alakjában javasolja felvenni.

Kulcsszavak: repedéstágasság, repedéskép, betonfedés, múgyanta injektálás

Ref.: http://dx.doi.org//10.14382/epitoanyag-jsbcm.2010.14

Borosnyói, A. - Snóbli, I..: Crack width variation within the concrete cover of reinforced concrete members. Építőanyag, 62. évf. 3. szám (2010), 70-74. p. 